\title{
Iron Bearing Minerals Flotation from Silica Sand Using Hydroxyl Surfactants
}

\author{
Suzan S. Ibrahim ${ }^{1 *}$ (i), Wael M. Fathy ${ }^{2}$ (i), Magdy A. Elsayed ${ }^{2}$, Tawfik R. Boulos ${ }^{1}$ (i) \\ ${ }^{1}$ Central Metallurgical Research and Development Institute, (CMRDI), Helwan, Cairo, Egypt \\ ${ }^{2}$ Al-Azhar University, Faculty of Engineering, Mining and Petroleum Dept., Cairo, Egypt \\ Email: *suzansibrahim@gmail.com,wael_fathy@egyptire.com,magdyabdo970@yahoo.com,trboulos83@gmail.com
}

How to cite this paper: Ibrahim, S.S., Fathy, W.M., Elsayed, M.A. and Boulos, T.R. (2021) Iron Bearing Minerals Flotation from Silica Sand Using Hydroxyl Surfactants. Journal of Minerals and Materials Characterization and Engineering, 9, 327-344.

https://doi.org/10.4236/jmmce.2021.94023

Received: May 31, 2021

Accepted: July 11, 2021

Published: July 14, 2021

Copyright $\odot 2021$ by author(s) and Scientific Research Publishing Inc. This work is licensed under the Creative Commons Attribution International License (CC BY 4.0).

http://creativecommons.org/licenses/by/4.0/

\begin{abstract}
A technological clayey sandstone sample from Wadi Qena locality, Eastern Desert of Egypt, was directed to processing. Fine kaolin and clean silica sand were produced after intensive attrition scrubbing of the sample. To increase the quality of the produced silica, it was subjected to reverse anionic flotation to minimize its iron content. In this respect, conventional flotation tests using three anionic oxyhydryl surfactants namely: sodium dodecyl benzene sulphonate, sodium naphtha sulphonate, and sodium dodecyl sulphate, were tried. Results showed a privilege action for sodium dodecyl sulphate to remove most of the iron oxide content of the sample. A statistical Box-Behnken design was constructed to optimize the process efficiency. It was shown that from a flotation feed contained $360 \mathrm{ppm} \mathrm{Fe}_{2} \mathrm{O}_{3}$ and $1190 \mathrm{ppm} \mathrm{Al}_{2} \mathrm{O}_{3}$, sand concentrate contained $29 \mathrm{ppm} \mathrm{Fe}_{2} \mathrm{O}_{3}$ and $564 \mathrm{ppm} \mathrm{Al}_{2} \mathrm{O}_{3}$, was produced. The optimum flotation conditions were $3.86 \mathrm{~kg} / \mathrm{t}$ sodium dodecyl sulphate dose, 3.22 flotation pulp pH, $1226 \mathrm{rpm}$ impeller speed, and $22.24 \mathrm{~L} / \mathrm{min}$ airflow rate. Variables interaction effects results showed that flotation separation efficiency was significantly influenced by air flow rate and cell impeller speed of the process.
\end{abstract}

\section{Keywords}

Iron Oxide/Silica Flotation, Anionic Surfactants, Affecting Variables

\section{Introduction}

Silica sands are often associated with undesirable minerals which impair transmission in optical fibers application and affect the transparency of different produced glasses. These harmful minerals are mainly iron bearing minerals which can be reduced by a number of physical, physicochemical or chemical 
methods. Yet, the proper choice has to depend mainly on what and how the mineralogy of these gangues in the silica sand sample. From these beneficiation processes, comes the reverse froth flotation technique. In flotation, the kinetic is generally of first order, where its rate is dependent on large number of variables. They can be grouped in three major components: chemical, operational and equipment variables [1]. Optimization of these variables is the keys to successful separation process. Among the chemical variables are the surfactants or the collectors that are being used to change the surface chemical properties of minerals to be separated [2]. The composition nature of these collectors, besides other parameters affecting their action performance on the separation process is still being studied [1] [2] [3].

From the collectors that are used in silica-iron oxides flotation processes come the anionic collectors [4]. These are, for instance, fatty acids, petroleum sulfonates, and alkyl sulfates collectors as derivatives of sulfuric acid in which one hydrogen atom has been replaced by a hydrocarbon radical. If the remaining hydrogen is connected directly with the carbon radical, then those collectors are called sulfoacids and their salts are sulfonates $\left(\mathrm{R}-\mathrm{CH}_{2}-\mathrm{SO}_{3} \mathrm{H}\right)$. If the carbon radical is connected with sulfur by an oxygen bridge, the compounds are called alkyl sulfate salts. Sulfate and sulfonate collectors are classing under the oxyhydryl anionic collectors (oxyhydryl referring to the $\mathrm{OH}$ group). Petroleum sulfonates possess similar properties to fatty acids, with less collecting power, but partly as a consequence, of greater selectivity. The long-chain carboxylates, sulfonates or sulfates produce adequate froth and serve the dual purpose of collector and frother in the flotation processes [5] [6] [7].

In this respect, the present research paper is dealing with the flotation of iron gangues from the attrition silica sand of a clayey sandstone deposit in Wadi Qena, Eastern Desert of Egypt, using three anionic collectors namely sodium dodecyl sulphonate SDBS, sodium naphtha sulphonate SNS, and sodium dodecyl sulphate SDS. The effect of collector dose, pulp $\mathrm{pH}$, impeller speed, and air flow rate during the flotation process was studied. Box-Behnken design (BBD) coupled with the response surface methodology (RSM) was applied to optimize statistically the flotation process using SDS collector and to illustrate the interaction effect of the detrimental variables on the separation efficiency.

\section{Experimental}

The attrition silica sand sample was directed to reverse anionic flotation technique. The tests were conducted using a "Denver D12" flotation cell. The conditioning step was conducted for 5 minutes at $2000 \mathrm{rpm}$ impeller speed and 50\% $60 \%$ pulp density. Throughout the experimental tests, the pulp density was diluted to reach $30 \%$ solid. Two anionic sulphonate surfactants were used as collectors: sodium naphtha sulphonate $\mathrm{SNS}\left(\mathrm{C}_{10} \mathrm{H}_{7} \mathrm{NaO}_{3} \mathrm{~S}\right)$, and sodium dodecylbenzene sulphonate $\left(\mathrm{C}_{12} \mathrm{H}_{25} \mathrm{C}_{6} \mathrm{H}_{4} \mathrm{SO}_{3} \mathrm{Na}\right)$. In addition, a sulphate type surfactant: sodium dodecyl sulphate $\left(\mathrm{CH}_{3}\left(\mathrm{CH}_{2}\right)_{11} \mathrm{SO}_{4} \mathrm{Na}\right)$ was also applied. The surfactants 
solutions were prepared as $10 \%$ stock solutions. However, they were used as $0.1 \%-0.5 \%$ concentration solutions. Commercial anti-foamer was sometimes added in trace amounts to regulate the collectors foaming power, especially the sulphonate ones. Conventional flotation runs using these collectors were carried up at different values of collector dose, flotation pulp $\mathrm{pH}$, flotation impeller speed, and aeration rate (air flow rate). The chemical analysis for iron and aluminum oxides contents of different products were conducted using plasma technique using ICP-MS unit.

A 4 factor 3 levels Box-Behnken design (BBD) was constructed to optimize the flotation process using sodium dodecyl sulphate collector (Table 1). In addition, the analysis of variance (ANOVA) was used to check the adequacy of the model of the experimentation tests.

\section{Results and Discussions}

\subsection{Sample Characterization}

The microscope investigation of the silica sand sample showed different modes of iron staining within sand grains, as well as different iron bearing minerals like magnetite, biotite, zircon, different types of rutile crystals, tourmaline (Figure 1). It was obvious that the particle size of most the accompanied gangue minerals were below 150 micron. The chemical analysis of the sand sample showed silicon dioxide content reached $99.75 \%$ (Table 2 ). In addition, appreciable contents of iron and alumina oxides reached $0.036 \%$, and $0.12 \%$, respectively, were present (Table 2). On the other hand, particle size distribution of the sand sample is shown in Table 3.

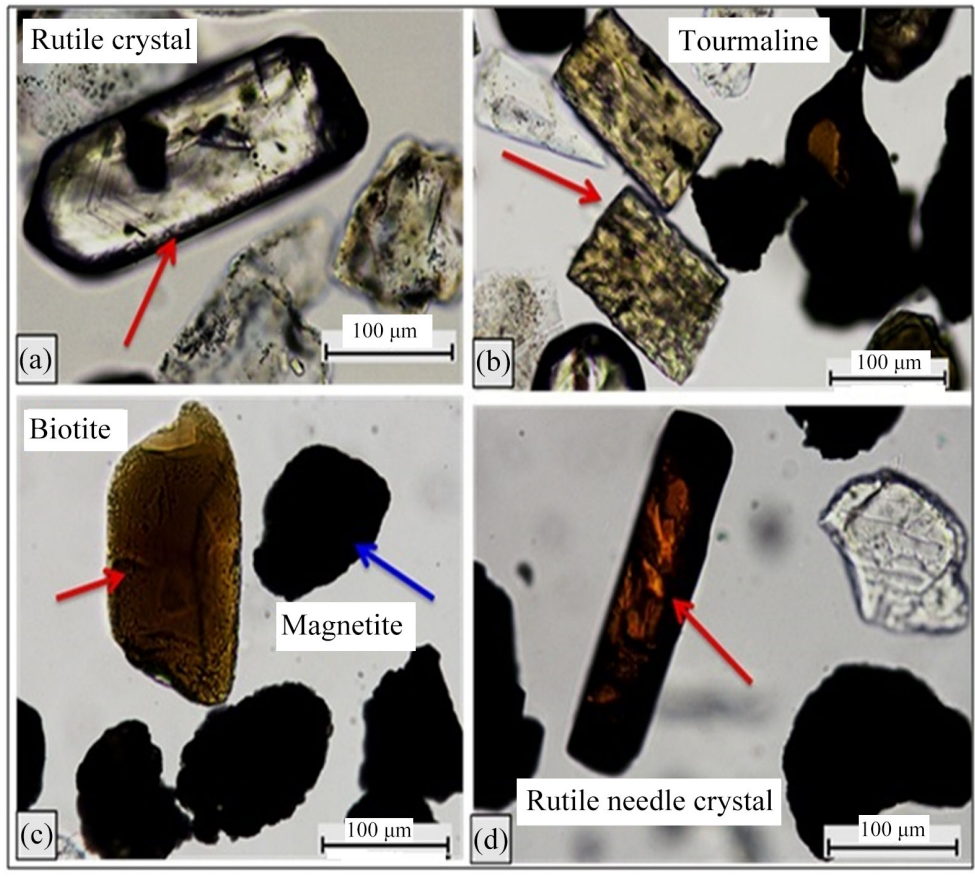

Figure 1. Photomicrograph of some gangues of the sample. 
Table 1. Levels of studied factors.

\begin{tabular}{cccccc}
\hline \multirow{2}{*}{ Symbol } & Factors & Units & \multicolumn{3}{c}{ Levels } \\
\cline { 4 - 6 } & & & Low $(-)$ & Mid (0) & High (+) \\
\hline$X_{1}$ & Dose & $\mathrm{kg} / \mathrm{t}$ & 3 & 4 & 5 \\
$X_{2}$ & $\mathrm{pH}$ & - & 2 & 3 & 4 \\
$X_{3}$ & Impeller speed & $\mathrm{rpm}$ & 1000 & 1250 & 1500 \\
$X_{4}$ & Air flow rate & L/min & 10 & 20 & 30 \\
\hline
\end{tabular}

$1 \mathrm{~L} / \mathrm{min}=0.001 \mathrm{~m}^{3} / \mathrm{min}$ (in SI units).

Table 2. Chemical analysis of the attrition sand sample.

\begin{tabular}{cc}
\hline Constituent & wt \% \\
$\mathrm{SiO}_{2}$ & 99.75 \\
$\mathrm{Al}_{2} \mathrm{O}_{3}$ & 0.12 \\
$\mathrm{Fe}_{2} \mathrm{O}_{3}$ & 0.036 \\
$\mathrm{TiO}_{2}$ & 0.038 \\
$\mathrm{CaO}$ & 0.023 \\
$\mathrm{P}_{2} \mathrm{O}_{5}$ & 0.006 \\
$\mathrm{Cl}$ & 0.017 \\
$\mathrm{SO}_{3}$ & 0.008 \\
$\mathrm{ZrO}_{2}$ & 0.018
\end{tabular}

Table 3. Particle size analysis of the attrition sand.

\begin{tabular}{ccc}
\hline Size fraction, $\mathrm{mm}$ & $\mathrm{wt} \%$ & Cum. Ret. wt $\%$ \\
\hline $0.60+0.42$ & 5.56 & 5.56 \\
$0.42+0.25$ & 43.18 & 48.74 \\
$0.25+0.21$ & 16.08 & 64.82 \\
$0.21+0.16$ & 22.22 & 87.04 \\
$0.16+0.106$ & 12.96 & 100 \\
Total & 100 & \\
\hline
\end{tabular}

\subsection{Reverse Anionic Flotation of Iron Gangues}

By applying the collectors with different doses at pulp pH 3, impeller speed 1500 $\mathrm{rpm}$, and air flow rate $20 \mathrm{~L} / \mathrm{min}$., flotation results showed their good response in decreasing iron and alumina oxides contents as shown in Figure 2(a). By using $4 \mathrm{~kg} / \mathrm{t}$, iron oxide and alumina contents decreased to $128 \mathrm{ppm} \mathrm{Fe}_{2} \mathrm{O}_{3}(64.15 \%$ removal) and $672 \mathrm{ppm} \mathrm{Al}_{2} \mathrm{O}_{3}(43.53 \%$ removal) in case of SDS. In addition, in case of SNS, the iron oxide content reached $203 \mathrm{ppm}$ (43.14\% removal), and 562 ppm $\mathrm{Al}_{2} \mathrm{O}_{3}$ (52.77\% removal) (Figure 2(a)). Additionally, by using $2 \mathrm{~kg} / \mathrm{t}$ of SDBS, the iron oxide and alumina contents were reduced to $153 \mathrm{ppm}$ and 646 ppm in sand product with removal efficiency reached $57.14 \%$ and $46 \%$, respectively (Figure 2(a)). 


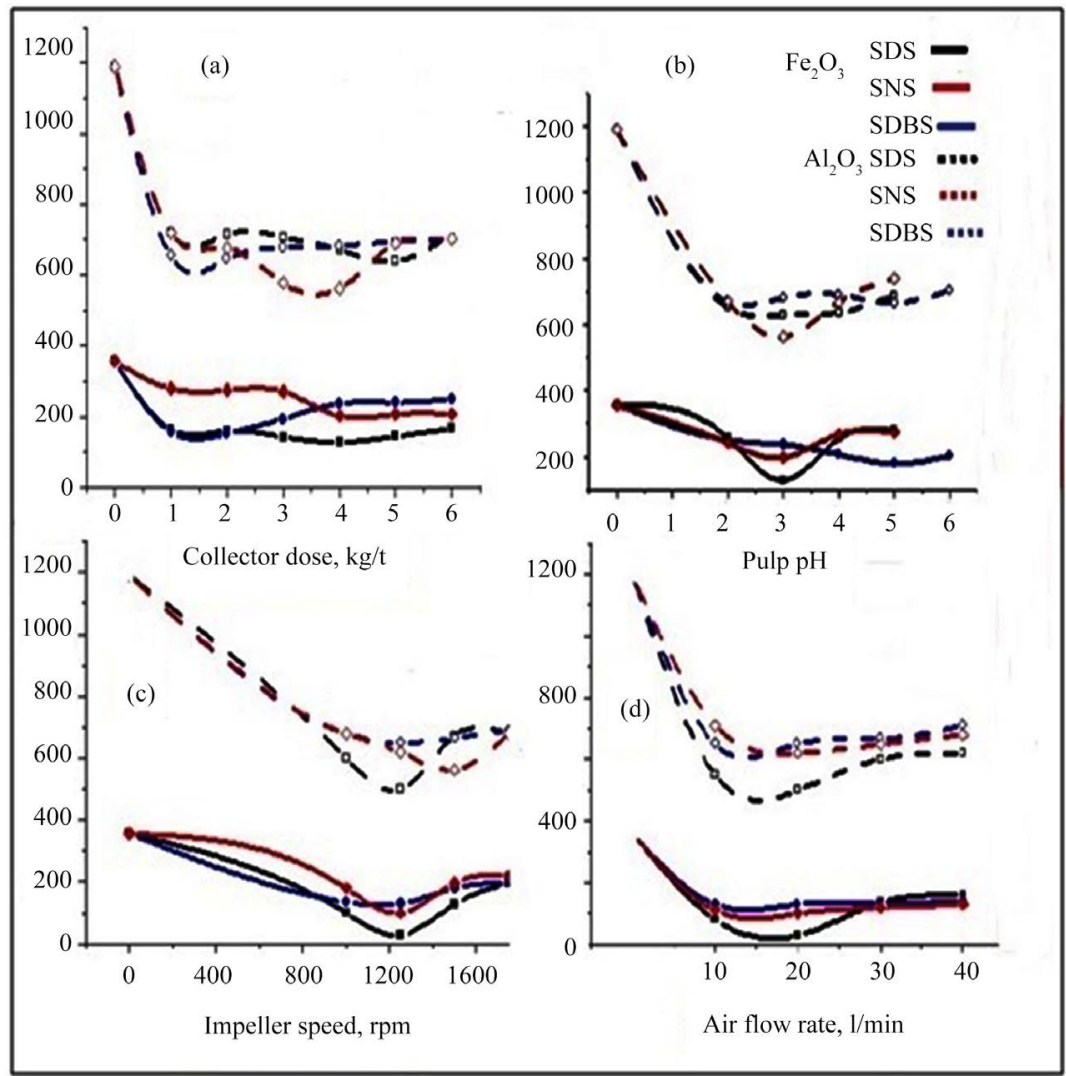

Figure 2. Effect of different working parameters on flotation efficiency.

It was noticed that at optimum collectors doses, no remarkable improvement in the removal yield of both oxides was noticed by changing the flotation pulp $\mathrm{pH}$ throughout the range between $\mathrm{pH}=2$ to $\mathrm{pH}=6$ (Figure 2(b)). However, by lowering the impeller speed during the flotation step from $1500 \mathrm{rpm}$ to 1250 $\mathrm{rpm}$, pronounced improving in the flotation efficiency of the three collectors was remarked (Figure 2(c)). The iron oxide content decreased to $29 \mathrm{ppm}, 130 \mathrm{ppm}$ and $100 \mathrm{ppm}$ for the three collectors SDS, SNS and SDBS (from $128 \mathrm{ppm}, 153$ ppm and $203 \mathrm{ppm}$ at impeller speed $1500 \mathrm{rpm}$, respectively) (Figure 2(c)). The removal improvement levels reached $77 \%, 51 \%$ and $15 \%$ for the three collectors, respectively (Figure $2(\mathrm{c})$ ), additionally, the alumina content showed remarkable improvement in case of using SDS as a collector by reducing the impeller speed, where it decreased to $500 \mathrm{ppm}$ at $1250 \mathrm{rpm}$ from $629 \mathrm{ppm}$ at $1500 \mathrm{rpm}$ (Figure $2(c))$. In addition, results showed no further improvement in the removal yield of both iron and alumina oxides for the three collectors by changing the flotation air flow rate away from the value of $20 \mathrm{l} / \mathrm{min}$ (Figure 2(d)). The flotation optimum condition of the three collectors is shown in Figure 3.

Impeller speed could affect on the flotation performance through controlling the turbulence level and hence the bubble-particle attachment rates inside the flotation pulp. Generally, at an impeller speed of $1000 \mathrm{rpm}$, where the turbulence was relatively at the lowest level i.e. at lowest bubble-particle attachment rate, resulting a decreasing in the flotation performance or recovery. Likewise, the 
same effect occurred at higher impeller speeds, e.g. $1500 \mathrm{rpm}$, where the higher turbulence caused weakening in the bubble-particle attachment that caused withdrawal in the separation efficiency. This behavior showed that a relatively lower impeller speed was sometimes more beneficial in having a longer contact time between collector and mineral particles because of the longer induction time required for bubble-particle attachment. However, for a given particle size, there is an optimum impeller speed that produces a good compromise between attachment and detachment rates in the cell for flotation. For less hydrophobic particles, a lower impeller speed is beneficial in having a longer contact time because of the longer induction time required for attachment [8]-[25].

Flotation using sodium naphthalene sulfonates SNS are providing excellent wetting, dispersing, with medium to low foaming action. They offer acid and base stability, hard-water tolerance, and high temperature stability. In addition, polar surface area of pure SNS is $65.6 \AA^{2}$ that helps to form emulsions by reducing the surface tension of the substances to be emulsified. However suspending agents are acting on the solid's surface characteristics that keep the particles from coming together and falling out of solution, On the other hand, sulphate collector (SDS) has the advantage of having a higher hardness tolerance than sulphonates collectors which are still quite sensitive to water hardness (Figure 4).

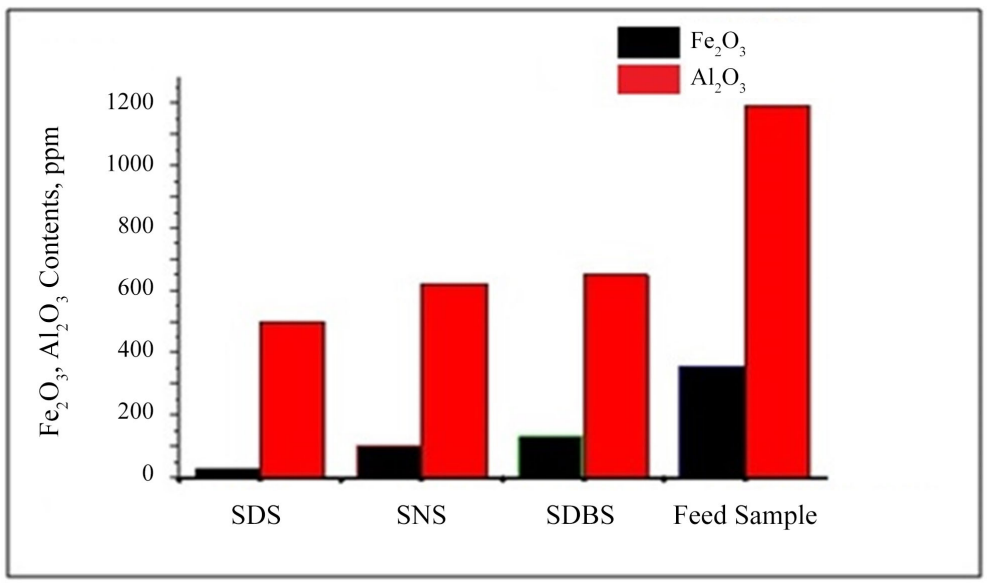

Figure 3. Flotation optimized conditions of the three collectors.

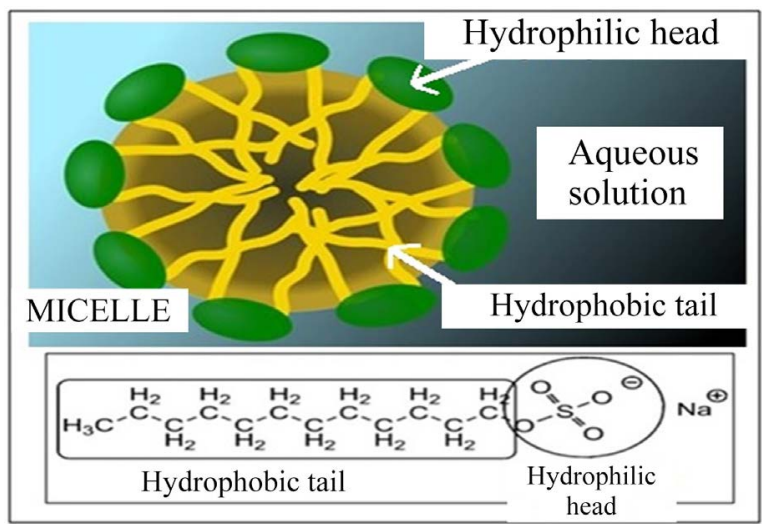

Figure 4. Molecular structure of sodium dodecyl sulfate [26]. 
Above a critical concentration, SDS forms micelles in water [26]. The concentration at which micelles start to form is the critical micelle concentration, CMC. At this point, surface tension becomes independent of concentration. An SLS micelle is spherical and has a diameter of roughly twice the length of SLS. It will contain 20 - 50 molecule, the sulfate heads face outwards forming the face of the sphere pointing towards the water. The long hydrocarbon chains, with then form the interior of the spherical micelle (Figure 4). The CMC of SLS is roughly $8.1 \mathrm{~mol} \cdot \mathrm{m}^{-3}$ at $25^{\circ} \mathrm{C}$. In addition, SDS has high polar surface area (the sum of surfaces of polar atoms, usually oxygen, and attached hydrogen atoms in a molecule) reaching $63.6 \AA^{2}$ compared to $54.37 \AA^{2}$ for SDBS [26].

\subsection{Statistical Optimizing of the Flotation Process}

Results of the 29 experimental runs proposed by BBD are given in Table 4. The cubic models for responses $Y_{1}$ (sand recovery wt \%), and $Y_{2}$ (iron oxide content, ppm), in addition to the quadratic model for response $Y_{3}$ (alumina content, ppm) were suggested in the form of regression equations in terms of coded variables. They showed good agreements between actual and predicted values, and hence lower standard deviation along with higher $\mathrm{R}^{2}$ values (Figure 5 ). The variance analysis results of the mathematical equations for the silica wt\%, $\mathrm{Fe}_{2} \mathrm{O}_{3}$, and $\mathrm{Al}_{2} \mathrm{O}_{3}$ contents in ppm are presented in Tables 5-7.

It is remarked that their model F-values are 10.97, 10.30, and 13.23, respectively, implied that the models were significant. The experimentally obtained data for each run is the actual value whereas the predicted value is the value that was evaluated from the model using the prediction equation by Design-Expert1 Software, Version 10.0 (Stat-Ease, Minneapolis, USA). From both plots, it was observed that the most of the data points were well distributed near to the straight line, suggested an excellent relationship between the experimental and predicted values of responses. Regression Equations (1), (2), and (3) of the three responses are illustrated.

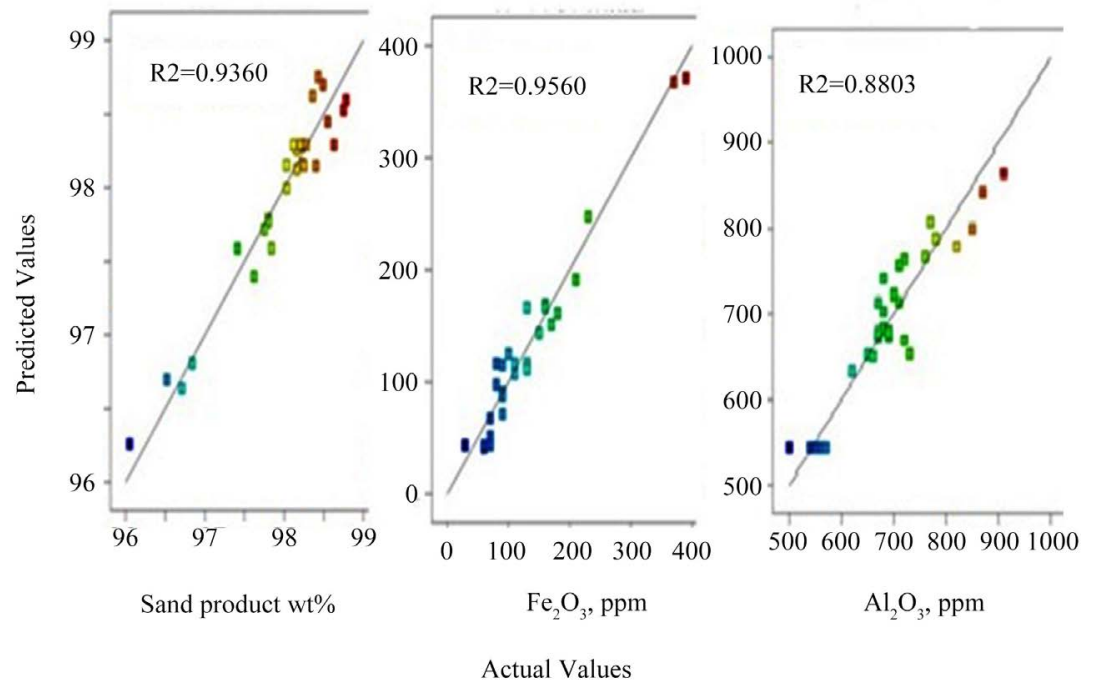

Figure 5. Correlation between actual and predicted responses values. 
Table 4. Box-Behnken design for developing and optimizing flotation process.

\begin{tabular}{|c|c|c|c|c|c|c|c|c|c|c|}
\hline \multirow{3}{*}{ Std } & \multicolumn{4}{|c|}{ Variables } & \multicolumn{6}{|c|}{ Responses } \\
\hline & \multirow{2}{*}{$X_{1}$} & \multirow{2}{*}{$X_{2}$} & \multirow{2}{*}{$X_{3}$} & \multirow{2}{*}{$X_{4}$} & \multicolumn{2}{|c|}{ wt $\%\left(Y_{1}\right)$} & \multicolumn{2}{|c|}{$\mathrm{Fe}_{2} \mathrm{O}_{3}, \operatorname{ppm}\left(Y_{2}\right)$} & \multicolumn{2}{|c|}{$\mathrm{Al}_{2} \mathrm{O}_{3}, \operatorname{ppm}\left(Y_{3}\right)$} \\
\hline & & & & & Actual & predicted & Actual & predicted & Actual & predicted \\
\hline 1 & 4 & 4 & 1500 & 20 & 97.62 & 97.40 & 160 & 166.25 & 720 & 670 \\
\hline 2 & 5 & 3 & 1250 & 30 & 98.23 & 98.16 & 90 & 115 & 910 & 864.17 \\
\hline 3 & 4 & 3 & 1250 & 20 & 98.2 & 98.29 & 70 & 43.4 & 550 & 544 \\
\hline 4 & 3 & 4 & 1250 & 20 & 98.43 & 98.75 & 150 & 143.75 & 700 & 722.92 \\
\hline 5 & 3 & 3 & 1500 & 20 & 98.16 & 98.19 & 70 & 51.25 & 690 & 691.25 \\
\hline 6 & 4 & 3 & 1250 & 20 & 98.12 & 98.29 & 60 & 43.4 & 560 & 544 \\
\hline 7 & 5 & 3 & 1000 & 20 & 98.16 & 98.06 & 210 & 191.25 & 760 & 779.58 \\
\hline 8 & 4 & 4 & 1000 & 20 & 98.55 & 98.45 & 130 & 166.25 & 670 & 673.33 \\
\hline 9 & 5 & 4 & 1250 & 20 & 98.22 & 98.28 & 90 & 91.25 & 770 & 807.92 \\
\hline 10 & 4 & 2 & 1250 & 10 & 97.8 & 97.77 & 90 & 71.25 & 710 & 757.92 \\
\hline 11 & 4 & 3 & 1250 & 20 & 98.23 & 98.29 & 29 & 43.4 & 570 & 544 \\
\hline 12 & 4 & 4 & 1250 & 10 & 97.75 & 97.72 & 170 & 151.25 & 620 & 632.92 \\
\hline 13 & 4 & 2 & 1000 & 20 & 98.25 & 98.15 & 110 & 116.25 & 730 & 653.33 \\
\hline 14 & 3 & 3 & 1250 & 30 & 97.84 & 97.59 & 80 & 97.5 & 820 & 779.17 \\
\hline 15 & 4 & 3 & 1000 & 30 & 98.49 & 98.70 & 70 & 67.5 & 680 & 742.08 \\
\hline 16 & 4 & 3 & 1250 & 20 & 98.63 & 98.29 & 29 & 43.4 & 540 & 544 \\
\hline 17 & 3 & 3 & 1250 & 10 & 98.4 & 98.15 & 230 & 247.5 & 710 & 714.17 \\
\hline 18 & 5 & 3 & 1250 & 10 & 96.71 & 96.64 & 100 & 125 & 850 & 799.17 \\
\hline 19 & 4 & 3 & 1250 & 20 & 98.28 & 98.29 & 29 & 43.4 & 500 & 544 \\
\hline 20 & 3 & 3 & 1000 & 20 & 98.78 & 98.66 & 60 & 41.25 & 680 & 669.58 \\
\hline 21 & 4 & 4 & 1250 & 30 & 98.03 & 98.00 & 130 & 111.25 & 870 & 842.92 \\
\hline 22 & 4 & 3 & 1500 & 10 & 96.52 & 96.70 & 90 & 87.5 & 690 & 673.75 \\
\hline 23 & 5 & 3 & 1500 & 20 & 97.8 & 97.85 & 180 & 161.25 & 720 & 751.25 \\
\hline 24 & 3 & 2 & 1250 & 20 & 98.36 & 98.62 & 160 & 168.75 & 680 & 702.92 \\
\hline 25 & 4 & 3 & 1000 & 10 & 96.05 & 96.26 & 370 & 367.5 & 650 & 652.08 \\
\hline 26 & 4 & 2 & 1500 & 20 & 98.75 & 98.54 & 80 & 116.25 & 660 & 650 \\
\hline 27 & 4 & 2 & 1250 & 30 & 96.84 & 96.81 & 390 & 371.25 & 670 & 677.92 \\
\hline 28 & 4 & 3 & 1500 & 30 & 97.41 & 97.59 & 110 & 107.5 & 670 & 713.75 \\
\hline 29 & 5 & 2 & 1250 & 20 & 98.03 & 98.15 & 130 & 116.25 & 780 & 116.25 \\
\hline
\end{tabular}


Table 5. ANOVA for response surface cubic model of $Y_{1}$ (silica product wt\%).

\begin{tabular}{cccccc}
\hline Source & $\begin{array}{c}\Sigma(\text { sum of } \\
\text { squares })\end{array}$ & $\Phi(\mathrm{DF})$ & $\begin{array}{c}\Psi \text { (mean } \\
\text { square })\end{array}$ & $\chi$ (F value $)$ & $\tau$ (Prob. $>$ F) \\
\hline Model & 11.78 & 16 & 0.74 & 10.97 & $<0.0001$ \\
$X_{1}$-collector dose & 0.66 & 1 & 0.66 & 9.87 & 0.0085 \\
$X_{2}$-pH & 0.32 & 1 & 0.32 & 4.84 & 0.0482 \\
$X_{3}$-flotation speed & 0.34 & 1 & 0.34 & 5.06 & 0.0440 \\
$X_{4}$-air flow rate & 2.77 & 1 & 2.77 & 41.29 & $<0.0001$ \\
$X_{1} X_{4}$ & 1.08 & 1 & 1.08 & 16.11 & 0.0017 \\
$X_{2} X_{3}$ & 0.51 & 1 & 0.51 & 7.61 & 0.0173 \\
$X_{2} X_{4}$ & 0.38 & 1 & 0.38 & 5.73 & 0.0340 \\
$X_{3} X_{4}$ & 0.60 & 1 & 0.60 & 8.95 & 0.0113 \\
$X_{1}^{2}$ & 0.081 & 1 & 0.081 & 1.20 & 0.2946 \\
$X_{2}^{2}$ & 0.016 & 1 & 0.016 & 0.24 & 0.6303 \\
$X_{3}^{2}$ & 0.29 & 1 & 0.29 & 4.30 & 0.0603 \\
$X_{4}^{2}$ & 3.84 & 1 & 3.84 & 57.24 & $<0.0001$ \\
$X_{1}^{2} X_{2}$ & 0.097 & 1 & 0.097 & 1.44 & 0.2530 \\
$X_{1}^{2} X_{4}$ & 0.70 & 1 & 0.70 & 10.46 & 0.0072 \\
$X_{2}^{2} X_{4}$ & 2.01 & 1 & 2.01 & 29.94 & 0.0001 \\
$X_{2} X_{3}^{2}$ & 0.49 & 1 & 0.49 & 7.23 & 0.0197 \\
Residual & 0.81 & 12 & 0.067 & & \\
Lack of Fit & 0.65 & 8 & 0.081 & 2.08 & 0.2504 \\
\hline & & & & &
\end{tabular}

Table 6. ANOVA for response surface cubic model $Y_{2}\left(\mathrm{Fe}_{2} \mathrm{O}_{3}\right.$, content, ppm).

\begin{tabular}{cccccc}
\hline Source & $\begin{array}{c}\Sigma(\text { sum of } \\
\text { squares })\end{array}$ & $\Phi(\mathrm{DF})$ & $\begin{array}{c}\Psi \text { (mean } \\
\text { square })\end{array}$ & $\chi$ (F value $)$ & $\tau$ (Prob. $>\mathrm{F}$ ) \\
\hline Model & $2.025 \mathrm{E}+005$ & 19 & $10,658.92$ & 10.30 & 0.0006 \\
$X_{1}$-collector dose & 5512.50 & 1 & 5512.50 & 5.32 & 0.0464 \\
$X_{2}$-pH & 8100.00 & 1 & 8100.00 & 7.82 & 0.0208 \\
$X_{3}$-flotation speed & $14,400.00$ & 1 & $14,400.00$ & 13.91 & 0.0047 \\
$X_{4}$-air flow rate & $19,600.00$ & 1 & $19,600.00$ & 18.93 & 0.0018 \\
$X_{1} X_{3}$ & 400.00 & 1 & 400.00 & 0.39 & 0.5496 \\
$X_{1} X_{4}$ & 4900.00 & 1 & 4900.00 & 4.73 & 0.0576 \\
$X_{2} X_{4}$ & $28,900.00$ & 1 & $28,900.00$ & 27.91 & 0.0005 \\
$X_{3} X_{4}$ & $25,600.00$ & 1 & $25,600.00$ & 24.73 & 0.0008 \\
$X_{1}^{2}$ & 5194.96 & 1 & 5194.96 & 5.02 & 0.0518 \\
$X_{2}^{2}$ & $22,046.85$ & 1 & $22,046.85$ & 21.30 & 0.0013 \\
$X_{3}^{2}$ & $10,146.18$ & 1 & $10,146.18$ & 9.80 & 0.0121 \\
$X_{4}^{2}$ & $36,049.96$ & 1 & $36,049.96$ & 34.82 & 0.0002 \\
\hline
\end{tabular}




\section{Continued}

\begin{tabular}{cccccc}
\hline$X_{1}^{2} X_{2}$ & 2112.50 & 1 & 2112.50 & 2.04 & 0.1869 \\
$X_{1}^{2} X_{3}$ & 6050.00 & 1 & 6050.00 & 5.84 & 0.0388 \\
$X_{1}^{2} X_{4}$ & 1800.00 & 1 & 1800.00 & 1.74 & 0.2199 \\
$X_{1} X_{3}^{2}$ & $22,204.17$ & 1 & $22,204.17$ & 21.45 & 0.0012 \\
$X_{2}^{2} X_{3}$ & 7200.00 & 1 & 7200.00 & 6.95 & 0.0270 \\
$X_{2}^{2} X_{4}$ & $36,450.00$ & 1 & $36,450.00$ & 35.21 & 0.0002 \\
$X_{2} X_{3}^{2}$ & 9800.00 & 1 & 9800.00 & 9.47 & 0.0132 \\
Residual & 9317.70 & 9 & 1035.30 & & \\
Lack of Fit & 7712.50 & 5 & 1542.50 & 3.84 & 0.1082 \\
\hline
\end{tabular}

Table 7. ANOVA response surface quadratic model of $Y_{3}\left(\mathrm{Al}_{2} \mathrm{O}_{3}\right.$ content, ppm).

\begin{tabular}{cccccc}
\hline Source & $\begin{array}{c}\Sigma(\text { sum of } \\
\text { squares })\end{array}$ & $\Phi(\mathrm{DF})$ & $\begin{array}{c}\Psi \text { (mean } \\
\text { square })\end{array}$ & $\chi$ (F value) & $\tau$ (Prob. $>\mathrm{F})$ \\
\hline Model & $2.332 \mathrm{E}+005$ & 10 & $23,318.34$ & 13.23 & $<0.0001$ \\
$X_{1}$-collector dose & $21,675.00$ & 1 & $21,675.00$ & 12.30 & 0.0025 \\
$X_{2}$-pH & 1200.00 & 1 & 1200.00 & 0.68 & 0.4201 \\
$X_{3}$-flotation speed & 33.33 & 1 & 33.33 & 0.019 & 0.8921 \\
$X_{4}$-air flow rate & $12,675.00$ & 1 & $12,675.00$ & 7.19 & 0.0152 \\
$X_{2} X_{4}$ & $21,025.00$ & 1 & $21,025.00$ & 11.93 & 0.0028 \\
$X_{3} X_{4}$ & 625.00 & 1 & 625.00 & 0.35 & 0.5589 \\
$X_{1}^{2}$ & $1.206 \mathrm{E}+005$ & 1 & $1.206 \mathrm{E}+005$ & 68.42 & $<0.0001$ \\
$X_{2}^{2}$ & $36,567.61$ & 1 & $36,567.61$ & 20.75 & 0.0002 \\
$X_{3}^{2}$ & $11,762.21$ & 1 & $11,762.21$ & 6.67 & 0.0187 \\
$X_{4}^{2}$ & $76,830.45$ & 1 & $76,830.45$ & 43.60 & $<0.0001$ \\
Residual & $31,720.00$ & 18 & 1762.22 & & \\
Lack of Fit & $28,800.00$ & 14 & 2057.14 & 2.82 & 0.1636 \\
\hline
\end{tabular}

$$
\begin{aligned}
Y_{1}= & +98.29-0.24 X_{1}+0.29 X_{2}-0.17 X_{3}+0.83 X_{4}+0.030 X_{1} X_{2} \\
& +0.52 X_{1} X_{4}-0.36 X_{2} X_{3}+0.31 X_{2} X_{4}-0.39 X_{3} X_{4}+0.11 X_{1}^{2} \\
& +0.050 X_{2}^{2}-0.21 X_{3}^{2}-0.77 X_{4}^{2}-0.22 X_{1}^{2} X_{2}-0.59 X_{1}^{2} X_{4} \\
& -1.0 X_{2}^{2} X_{4}-0.49 X_{2} X_{3}^{2} \\
Y_{2}= & +43.40-26.25 X_{1}-45.00 X_{2}-60.00 X_{3}-70.00 X_{4} \\
& -7.50 X_{1} X_{2}-10.0 X_{1} X_{3}+57.50 X_{1} X_{4}+15.00 X_{2} X_{3} \\
& -85.00 X_{2} X_{4}+80.00 X_{3} X_{4}+35.80 X_{1}^{2}+54.55 X_{2}^{2}+35.8 X_{3}^{2} \\
& +82.05 X_{4}^{2}+32.50 X_{1}^{2} X_{2}+55.00 X_{1}^{2} X_{3}+7.50 X_{1}^{2} X_{4} \\
& +102.50 X_{1} X_{3}^{2}+60.00 X_{2}^{2} X_{3}+135.00 X_{2}^{2} X_{4}+70.00 X_{2} X_{3}^{2} \\
Y_{3}= & +544.67+42.50 X_{1}+5.83 X_{2}-5.83 X_{3}+32.50 X_{4} \\
& +72.50 X_{2} X_{4}-12.50 X_{3} X_{4}+138.42 X_{1}^{2}+70.92 X_{2}^{2} \\
& +38.42 X_{3}^{2}+110.92 X_{4}^{2}
\end{aligned}
$$


It is clear from Equation (2) that the constant 43.40 was independent of any factor or interaction of the factors. It showed that the model was highly significant as the Fisher F-test $\left(\mathrm{F}\right.$ model, $\left.\mathrm{S}^{2} \mathrm{reg} / \mathrm{S}^{2} \mathrm{err}=10.30\right)$ with a very low probability value $[(\mathrm{P}>\mathrm{F})=0.0006]$ (Table 6$)$.

The main effect $X_{1}, X_{2}, X_{3}, X_{4}$; the two-level interactions of collector dose and air flow rate $\left(X_{1} X_{4}\right), \mathrm{pH}$ and air flow rate $\left(X_{2} X_{4}\right)$, flotation speed and air flow rate $\left(X_{3} X_{4}\right)$; the second-order effect of $\mathrm{pH}\left(X_{2}^{2}\right)$, flotation speed $\left(X_{3}^{2}\right)$, and air flow rate $\left(X_{4}^{2}\right)$ and the third-order effect $X_{1}^{2} X_{3}, X_{1} X_{3}^{2}, X_{2}^{2} X_{3}, X_{2}^{2} X_{4}, X_{2} X_{3}^{2}$ were the significant model terms.

Other model terms were statistically insignificant. It was found that the coefficient of determination $\left(\mathrm{R}^{2}\right)$ was 0.9560 , which was very high and has indicated a good correlation. As well, the adjusted $\mathrm{R}^{2}$ value $(0.8632)$ was high to advocate the significance of the model, which ensured a satisfactory adjustment of the experimental data to the polynomial model. The ratio of 12.350 for response $Y_{2}$ indicated an adequate signal and so the model could be used to navigate the design space. Simultaneously, a low value of the coefficient of variation $(\mathrm{CV}=25.45 \%)$ denoted good accuracy and reliability of the experiments.

From Equation (2), the linear terms $X_{1}, X_{2}, X_{3}, X_{4}$, and the interaction terms $X_{1} X_{3}, X_{2} X_{4}$ had an antagonistic effect on the responses and hence synergistic effect on the grade of the produced silica in the order of $X_{4}>X_{3}>X_{2}>X_{1}$. In addition, the interaction terms $X_{1} X_{4}, X_{3} X_{4}$, quadratic terms $X_{1}^{2}, X_{2}^{2}, X_{3}^{2}, X_{4}^{2}$, and the third order $X_{1}^{2} X_{2}, X_{1}^{2} X_{3}, X_{1}^{2} X_{4}, X_{1} X_{3}^{2}, X_{2}^{2} X_{3}, X_{2}^{2} X_{4}, X_{2} X_{3}^{2}$, had a synergistic effect on the responses. The variables interaction effects are in the order of $X_{2} X_{4}>X_{3} X_{4}>X_{1} X_{4}>X_{2} X_{3}>X_{1} X_{3}>X_{1} X_{2}$, as shown in Equation (2).

The linear one factor plot diagrams after the design showed that by increasing the SDS dose from $3 \mathrm{~kg} / \mathrm{t}$ to $5 \mathrm{~kg} / \mathrm{t}$, the iron oxide content decreased from 119 ppm to $46 \mathrm{ppm}$, yet it showed minimum content reached $43 \mathrm{ppm}$ at $4 \mathrm{~kg}$ (at pulp $\mathrm{pH}=3$, flotation speed $=1250 \mathrm{rpm}$, and air flow rate $=20 \mathrm{~L} / \mathrm{min}$ ). Where, at $\mathrm{pH}=2$, the iron oxide content reached $146 \mathrm{ppm}$, and showed decrease to 37 $\mathrm{ppm}$ at $\mathrm{pH}=3.5$, followed by another increase to $66 \mathrm{ppm}$ by increasing the pulp $\mathrm{pH}$ to the value 4 (at SDS dose $=4 \mathrm{~kg} / \mathrm{t}$, flotation speed $=1250 \mathrm{rpm}$, and flotation air flow rate $=20 \mathrm{~L} / \mathrm{min}$ ). By increasing the impeller speed during flotation from $1000 \mathrm{rpm}$ to $1500 \mathrm{rpm}$, the iron oxide content in the produced silica decreased from $140 \mathrm{ppm}$ to $26 \mathrm{ppm}$ (at $\mathrm{pH}=3$, SDS dose $=4 \mathrm{~kg} / \mathrm{t}$, and air flow $=$ $20 \mathrm{~L} / \mathrm{min}$ ). At aeration rate $10 \mathrm{~L} / \mathrm{min}$, the iron oxide reached $197 \mathrm{ppm}$ and showed remarkable decrease to $26.6 \mathrm{ppm}$ by increasing the aeration rate to 25 $\mathrm{L} / \mathrm{min}$, and then it showed another increase to $59 \mathrm{ppm}$ at $30 \mathrm{~L} / \mathrm{min}$ (at SDS dose $=4 \mathrm{~kg} / \mathrm{t}$, pulp $\mathrm{pH}=3$, and flotation impeller speed $=1250 \mathrm{rpm}$ ).

\subsection{Variables Interaction Effects}

The interaction effect between collector dose and pulp $\mathrm{pH}$ (at impeller speed $1250 \mathrm{rpm}$, and air flow rate $20 \mathrm{~L} / \mathrm{min}$ ) was demonstrated in Figure 6(a). The interaction showed reversible effect on the $\mathrm{Fe}_{2} \mathrm{O}_{3}$ content in the produced silica product. It was noticed that as the collector dose increased from $3 \mathrm{~kg} / \mathrm{t}$ to 4.5 
$\mathrm{kg} / \mathrm{t}$, the $\mathrm{Fe}_{2} \mathrm{O}_{3}$ content decreased from $164 \mathrm{ppm}$ to $29 \mathrm{ppm}$ at pulp $\mathrm{pH}$ 2. Moreover, it decreased from $186 \mathrm{ppm}$ to $135 \mathrm{ppm}$ by increasing the pulp $\mathrm{pH}$ to the value 4 (Figure 6(a)). In addition, as the collector dose increased from $4.5 \mathrm{~kg} / \mathrm{t}$ to $5 \mathrm{~kg} / \mathrm{t}$, the $\mathrm{Fe}_{2} \mathrm{O}_{3}$ content decreased from $130 \mathrm{ppm}$ to $114 \mathrm{ppm}$ at pulp $\mathrm{pH}=2$. Yet, it increased from $50 \mathrm{ppm}$ to $74 \mathrm{ppm}$ when the pulp pH increased to the value 4 (Figure 6(a)).

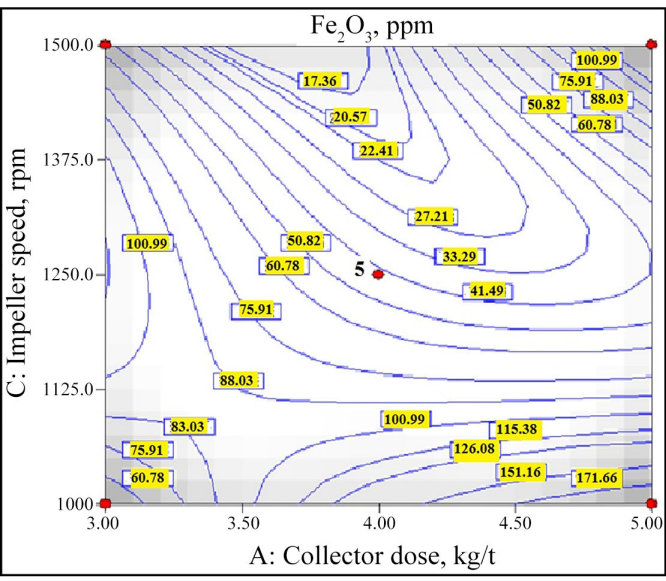

(a)

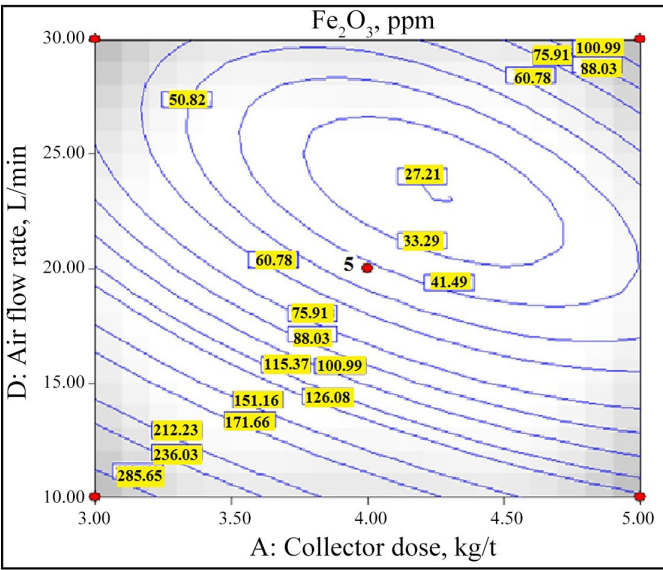

(c)

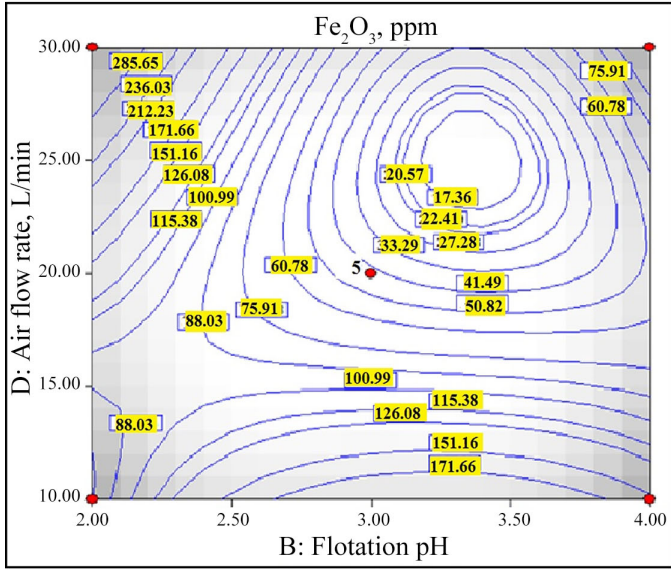

(e)

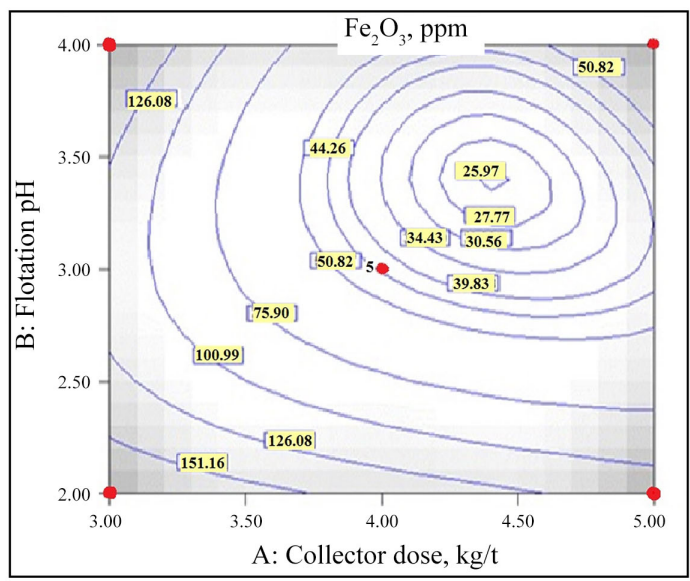

(b)

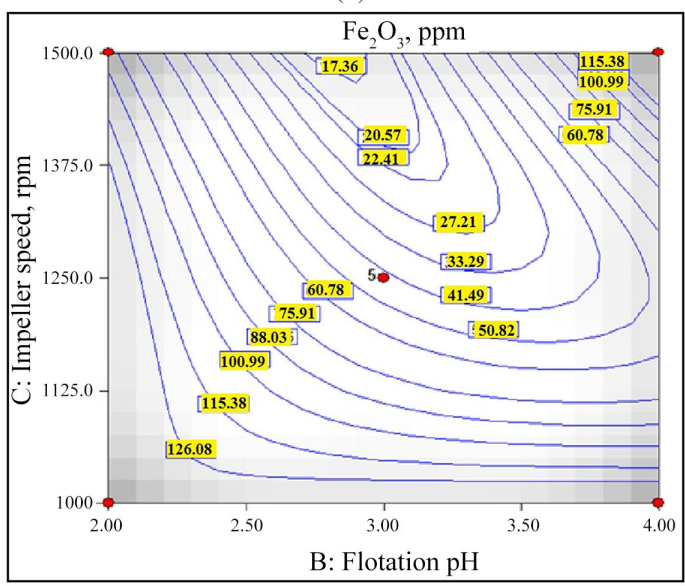

(d)

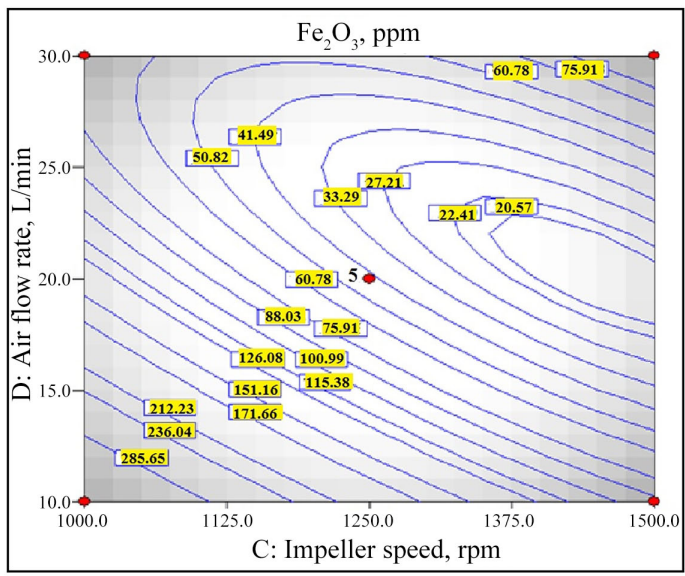

(f)

Figure 6. Interaction effects of different variables on $\mathrm{Fe}_{2} \mathrm{O}_{3}$ content. 
The interaction effect between the collector dose and the flotation impeller speed showed reversible influence on the $\mathrm{Fe}_{2} \mathrm{O}_{3}$ content in the produced silica sand. When the collector dose increased from $3 \mathrm{~kg} / \mathrm{t}$ to $3.50-3.75 \mathrm{~kg} / \mathrm{t}$, the iron oxide content decreased from $49.30 \mathrm{ppm}$ to $18.86 \mathrm{ppm}$ at flotation speed 1500 $\mathrm{rpm}$ (at pulp $\mathrm{pH}=3$, and air flow rate $=20 \mathrm{~L} / \mathrm{min}$ ). However, by increasing the collector dose above $4 \mathrm{~kg} / \mathrm{t}$ at the same flotation speed $1500 \mathrm{rpm}$, the iron oxide content showed gradual increase as illustrated in Figure 6(b). On the other hand, by decreasing the flotation speed to $1000 \mathrm{rpm}$, all the iron oxide contents showed increasing in their values reached 94, 118, 143, and $165 \mathrm{ppm}$ at collector doses 3.5, 3.75, 4.00, and $4.50 \mathrm{~kg} / \mathrm{t}$, respectively (Figure 6(b)).

Interaction effect between collector dose and flotation air flow rate (at pulp $\mathrm{pH}=3$, and flotation speed $=1250 \mathrm{rpm}$ ) showed remarkable irreversible action on the iron oxide content in the produced silica (Figure 6(c)). At flotation air flow rate 30 l/min, when the collector dose increased from $3 \mathrm{~kg} / \mathrm{t}$ to $3.5-4.0 \mathrm{~kg} / \mathrm{t}$, the content of the iron oxide decreased from $75 \mathrm{ppm}$ to $50 \mathrm{ppm}$, then it showed an increase again to $75 \mathrm{ppm}$ by increasing the collector dose to $4.5 \mathrm{~kg} / \mathrm{t}$. By increasing the collector dose to $5 \mathrm{~kg} / \mathrm{t}$, the iron oxide continued its increase to 124 ppm. At flotation air flow rate $10 \mathrm{~L} / \mathrm{min}$, the gradual increasing in the collector dose from $3 \mathrm{~kg} / \mathrm{t}$ to $5 \mathrm{~kg} / \mathrm{t}$ showed gradual decrease in the content of iron oxide as shown in Figure 6(c).

Interaction between pulp $\mathrm{pH}$ and the flotation speed showed relatively low irreversible effect on the content of iron oxide in the produced silica at collector dose $4 \mathrm{~kg} / \mathrm{t}$ and at $20 \mathrm{~L} / \mathrm{min}$ flotation air flow rate (Figure 6(d)). At flotation impeller speed $1000 \mathrm{rpm}$, it was noticed that a small change was occurred throughout all the pulp $\mathrm{pH}$ values from 2 to 5 , where the iron oxide content increased from $124 \mathrm{ppm}$ at pulp $\mathrm{pH}=2.0$ to $143 \mathrm{ppm}$ at pulp $\mathrm{pH}$ range $3-4$ (Figure 6(d)). At flotation speed $1500 \mathrm{rpm}$, great change in the behavior of the iron oxide content compared to that at flotation speed $=1000 \mathrm{rpm}$ (Figure $6(\mathrm{~d})$ ). At pulp $\mathrm{pH}=2.75$ and flotation impeller speed $1500 \mathrm{rpm}$, a very low content for $\mathrm{Fe}_{2} \mathrm{O}_{3}$ reached $15.70 \mathrm{ppm}$ was recorded (Figure 6(d)).

Air flow rate (AFR) influences flotation in two ways. One is by its influence on the bubble surface area and water recovery, which subsequently affects the transfer rate of solid materials from froth over the cell lip and from the pulp to froth which leads to entrainment. The other is the effect on the power input which changes the suspension of particles and reduces collision. The overall effect of AFR on flotation results are shown at high AFR, the grade of concentrate is reduced and the recovery is increased due to entrainment. The results imply that the entrainment is the major effect of AFR [9] [10] [11] [12] [13].

The interaction between the flotation pulp $\mathrm{pH}$ and the air flow rate represented the most effective parameter affecting the flotation process efficiency using SDS collector. This effect showed reversible action on the iron oxide content and hence an irreversible effect in the grade of the produced silica (Figure 6(e)). At air flow rate $30 \mathrm{~L} / \mathrm{min}$, the flotation process showed great variation in its efficiency throughout the pulp $\mathrm{pH}$ range from the value 2.0 to the 
value $\mathrm{pH}=4.0$ (at collector dose $4 \mathrm{~kg} / \mathrm{t}$, and flotation impeller speed $1250 \mathrm{rpm}$ ) (Figure 6(e)). At pulp pH 2 and air flow rate $30 \mathrm{~L} / \mathrm{min}$, the iron oxide reached about $374 \mathrm{ppm}$, then it showed sharp decrease by increasing the acidity of the pulp to reach $37.5 \mathrm{ppm}$ at $\mathrm{pH}=3.25-3.50$ (Figure 6(e)). In addition, it showed an increase to about $112.5 \mathrm{ppm}$ by increasing the pulp pH to the value 4 (Figure $6(\mathrm{e}))$. At flotation air flow rate $10 \mathrm{~L} / \mathrm{min}$, the change in the iron oxide content throughout the pulp $\mathrm{pH}$ range from 2 to the value 4, was within the value 75 $\mathrm{ppm}($ at $\mathrm{pH}=2.0$ ), and to $200 \mathrm{ppm}$ (at $\mathrm{pH}=3.25$ ), then it showed a decrease to about $143 \mathrm{ppm}$ at $\mathrm{pH} 4.0$ (Figure 6(e)).

The influence of the interaction between the impeller speeds and the air flow rate during the flotation stage, on the iron oxide removal from the silica (at collector dose $4 \mathrm{~kg} / \mathrm{t}$, and pulp $\mathrm{pH}$ 3) came much closed to the effect of the interaction between the pulp pH and the flotation impeller speed, but with an opposite effect. At flotation air flow rate $10 \mathrm{~L} / \mathrm{min}$, the increase in the speed impeller showed remarkable decrease in the iron oxide content (Figure 6(f)). The iron oxide recorded $370 \mathrm{ppm}$ at flotation speed $1000 \mathrm{rpm}$. This iron content concentration decreased gradual with the increase in the impeller speed till reached 46 ppm at $1500 \mathrm{rpm}$ (Figure 6(f)). At flotation air flow rate $30 \mathrm{~L} / \mathrm{min}$, the change of the iron oxide content with the change in the impeller speed was very modest (Figure 6(f)). The iron oxide content reached $71 \mathrm{ppm}$ at impeller speed 1000 $\mathrm{rpm}$, and then it showed a minimum content reached $55 \mathrm{ppm}$ throughout the impeller speed range 1125 - $1250 \mathrm{rpm}$ (Figure 6(f)). By increasing the speed to $1500 \mathrm{rpm}$, the iron oxide increased to $105 \mathrm{ppm}$ (Figure 6(f)).

Impeller speed (IPS) has two effects; one is the effect on the power input which can increase either collision between the particles and bubbles or the detachment of particles from bubbles. The other effect is on the dispersion of bubbles which may eventually affect the bubble surface area, the recovery of fine particles and water recovery. The effect of IPS on the recovery of coarse particles is negative and on the fine particles is positive. This conclusion is that for the coarse particles, the first effect is dominant and for the fine particles the second is dominant. However, it could be concluded that the effects of the impeller speed (IPS) are related to the turbulence in the flotation pulp. However, in order to find the effect of IPS on flotation kinetics irrespective of the shape of impellers, power input can be measured. Once the general relationship between the power input (the power for which particles can be suspended in the pulp) and the flotation rate is obtained in different flotation cells by using a multiplier, a new relation can be used. Generally, the increase in the process power input, will improve the flotation rate. However at relatively high power input, the flotation rate becomes unstable and is losing its performance due to excessive turbulence in the flotation pulp. It was proved that the increase in IPS results in two effects, first an increase in power input leads to an increase in flotation rate, but after $1300 \mathrm{rpm}$ further increase in IPS results in a decrease in flotation rate [9] [10] [11] [12]. By using the numerical optimization of the overall desirability function reaching 0.918 of the design, it was concluded that at a collector dose $=3.86$ 


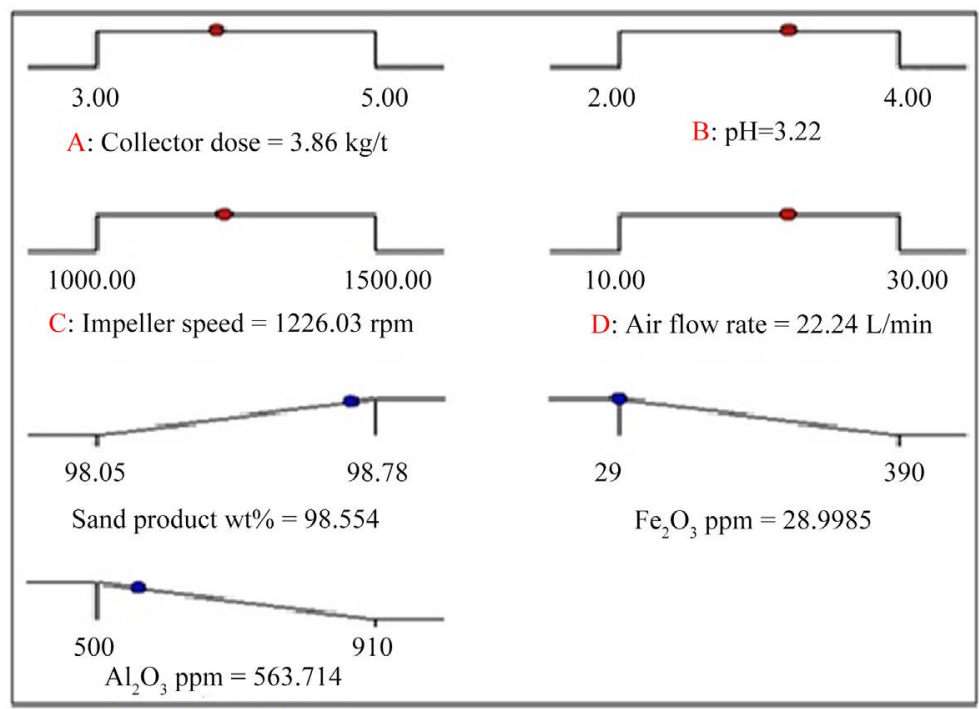

Figure 7. Optimization of the flotation process.

$\mathrm{kg} / \mathrm{t}$, pulp $\mathrm{pH}=3.22$, flotation impeller speed $=1226 \mathrm{rpm}$, and airflow rate $=$ 22.24 $\mathrm{L} / \mathrm{min}$, the cleanest silica sand product was produced. This product showed a weight recovery reached $98.55 \%$ with iron and aluminum oxides contents reaching $29 \mathrm{ppm}$ and $564 \mathrm{ppm}$, respectively (Figure 7).

\section{Conclusions}

In this study three oxyhydryl surfactants: sodium dodecyl benzene sulphonate, sodium naphtha sulphonate, and sodium dodecyl sulphate, were tried as anionic collectors in the reverse flotation tests to minimize iron contaminants from silica sand sample. A statistical Box-Behnken design was rather constructed to analyze the effect of different variables on the flotation performance using sodium dodecyl sulphate. The core outcomes of the study are summarized below:

The conventional flotation tests showed preferability on using SDS as an anionic collector in reducing the iron content in the clean silica. Iron and alumina oxides contents reduced from $0.036 \%$ and $0.119 \%$ in the feed sample to $0.0029 \%$ and $0.050 \%$ in the sand concentrate, with removal efficiency reached $92 \%$ and $58 \%$, respectively. The optimum flotation conditions were: $4 \mathrm{~kg} / \mathrm{t}$ SDS at pulp pH 3, impeller speed $1250 \mathrm{rpm}$ and air flow rate $20 \mathrm{~L} / \mathrm{min}$.

Statistical optimization of the flotation process using sodium dodecyl sulphate was carried out using Box-Behnken design (BBD) coupled with the Response Surface Methodology (RSM). Four variables including: collector dose, pulp pH, impeller speed and air flow rate were applied. In addition, three responses including clean sand wt\%, iron and aluminum oxides contents in ppm were inserted. ANOVA results showed that two cubic models (sand wt\%), and iron oxide content, and one quadratic model (aluminum oxide content), were found to express the functional relationship between the three responses and the four independent variables. The correlation coefficients $\left(R^{2}\right)$ were resulted as 0.9360 , 0.9560 and 0.8803 for the three responses, in sequence showed good fit of the 
experimental data of the model. Results showed that the two responses A and B were significantly influenced by the interaction effect of the collector dose and the air flow rate, whereas the response $\mathrm{C}$ was significantly influenced by the interaction effect between the flotation pulp $\mathrm{pH}$ and the air flow rate during flotation.

Optimization of the flotation process that was performed on the basis of the desirability function showed that maximum sand concentrate weight recovery reached $98.55 \%$ could be obtained with minimal iron oxide content, and aluminum oxide content reached $29 \mathrm{ppm}$ and $564 \mathrm{ppm}$, respectively. The flotation optimum conditions were: sodium dodecyl sulphate dose $(3.86 \mathrm{~kg} / \mathrm{t}), \mathrm{pH}(3.22)$, impeller speed $(1226 \mathrm{rpm})$ and airflow rate $(22.24 \mathrm{~L} / \mathrm{min})$. These results were further validated by the actually performing experiment at the optimized values and they were found to be in a satisfied agreement with those that were predicted by the model.

\section{Conflicts of Interest}

The authors declare no conflicts of interest regarding the publication of this paper.

\section{References}

[1] Kawatra, S.K. (2011) Fundamental Principles of Froth Flotation. In: Darling, P., Ed., SME Mining Engineering Handbook, Vol. 2, 3rd Edition, Society for Mining Metallurgy and Exploration, Littleton, CO, 1517-1531.

[2] Wills, B.A. and Finch, J. (2015) Wills' Mineral Processing Technology: An Introduction to the Practical Aspects of Ore Treatment and Mineral Recovery. 8th Edition, Butterworth-Heinemann, Oxford. https://doi.org/10.1016/C2010-0-65478-2

[3] Balagueiras, F. (2015) Application of a Novel Green Collector for Iron Oxide Removal in Glass Sand through Froth Flotation. Geologic and Mine Engineering Department, Instituto Superior Técnico, Lisboa.

[4] Zhang, X., Gu, X., Han, Y., Álvarez, N.P., Claremboux, V. and Kawatra, S.K. (2021) Flotation of Iron Ores: A Review. Mineral Processing and Extractive Metallurgy Review, 42, 184-212. https://doi.org/10.1080/08827508.2019.1689494

[5] Kobayashi, M., Yuki, S. and Adachi, V. (2016) Effect of Anionic Surfactants on the Stability Ratio and Electrophoretic Mobility of Colloidal Hematite Particles. Colloids and Surfaces A: Physicochemical and Engineering Aspects, 510, 190-197. https://doi.org/10.1016/j.colsurfa.2016.07.063

[6] Quast, K. (2017) Literature Review on the Use of Natural Products in the Flotation of Iron Oxide Ores. Minerals Engineering, 108, 12-24. https://doi.org/10.1016/j.mineng.2017.01.008

[7] Nakhaei, F. and Irannajad, M. (2018) Reagents Types in Flotation of Iron Oxide Minerals: A Review. Mineral Processing and Extractive Metallurgy Review, 39, 89-124. https://doi.org/10.1080/08827508.2017.1391245

[8] Seguel, F., Soto, I., Krommenacker, N., Maldonado, M. and Becerra-Yoma, N. (2015) Optimizing Flotation Bank Performance through Froth Depth Profiling: Revisited. Minerals Engineering, 77, 179-184.

https://doi.org/10.1016/j.mineng.2015.03.008 
[9] Meng, J., Tabosa, E., Xie, W., Runge, K. and Bradshaw, D. (2016) A Review of Turbulence Measurement Techniques for Flotation. Minerals Engineering, 95, 79-95. https://doi.org/10.1016/j.mineng.2016.06.007

[10] Sovechles, J.M., Lepage, M.R., Johnson, B. and Waters, K.E. (2016) Effect of Gas Rate and Impeller Speed on Bubble Size in Frother-Electrolyte Solutions. Minerals Engineering, 99, 133-141. https://doi.org/10.1016/j.mineng.2016.08.021

[11] Meng, J., Xie, W., Tabosa, E., Runge, K. and Bradshawa, D. (2016) Turbulence Model Development for Flotation Cells Based on Piezoelectric Sensor Measurements. International Journal of Mineral Processing, 156, 116-126. https://doi.org/10.1016/j.minpro.2016.05.013

[12] Nguyen, A.V., An-Vo, D.-A., Tran-Cong, T. and Evans, G.M. (2016) A Review of Stochastic Description of the Turbulence Effect on Bubble-Particle Interactions in Flotation. International Journal of Mineral Processing, 156, 75-86. https://doi.org/10.1016/j.minpro.2016.05.002

[13] Xie, W., Meng, J. and Nguyen, A.V. (2016) Experimental Quantification of Turbulence and Its Applications in the Study of Multiphase Flotation Pulps. International Journal of Mineral Processing, 156, 87-98. https://doi.org/10.1016/j.minpro.2016.06.011

[14] Amini, E., Bradshaw, D.I. and Xie, W. (2016) Influence of Flotation Cell Hydrodynamics on the Flotation Kinetics and Scale up, Part 1: Hydrodynamic Parameter Measurements and Ore Property Determination. Minerals Engineering, 99, 40-51. https://doi.org/10.1016/j.mineng.2016.09.024

[15] Tabosa, E., Runge, K., Holtham, P. and Duffy, K. (2016) Improving Flotation Energy Efficiency by Optimizing Cell Hydrodynamics. Minerals Engineering, 96-97, 194-202. https://doi.org/10.1016/j.mineng.2016.05.002

[16] Safari, M., Harris, M., Deglon, D., Filho, L.L. and Testa, F. (2016) The Effect of Energy Input on Flotation Kinetics. International Journal of Mineral Processing, 156, 108-115. https://doi.org/10.1016/j.minpro.2016.05.008

[17] Yianatos, J., Bergh, L., Vinnett, L., Panire, I. and Iriarte, V. (2016) Correlation between the Top of Froth Grade and the Operational Variables in Rougher Flotation Circuits. Minerals Engineering, 99, 151-157. https://doi.org/10.1016/j.mineng.2016.08.018

[18] Xing, Y., Gui, X., Pan, L., Pinchasik, B.E., Cao, Y., Liu, J., Kappl, M. and Butt, H.J. (2017) Recent Experimental Advances for Understanding Bubble-Particle Attachment in Flotation. Advances in Colloid and Interface Science, 246, 105-132. https://doi.org/10.1016/j.cis.2017.05.019

[19] Shean, B., Hadler, K. and Cilliers, J.J. (2017) A Flotation Control System to Optimize Performance Using Peak Air Recovery. Chemical Engineering Research and Design, 117, 57-65. https://doi.org/10.1016/j.cherd.2016.10.021

[20] Norori-Mccormac, A., Brito-Parada, P.R., Hadler, K., Cole, K. and Cilliers, J.J. (2017) The Effect of Particle Size Distribution on Froth Stability in Flotation. Separation and Purification Technology, 184, 240-247. https://doi.org/10.1016/j.seppur.2017.04.022

[21] Li, D., Yin, W., Liu, Q., Cao, S., Sun, Q., Zhao, C. and Yao, J. (2017) Interactions between Fine and Coarse Hematite Particles in Aqueous Suspension and Their Implications for Flotation. Minerals Engineering, 114, 74-81. https://doi.org/10.1016/j.mineng.2017.09.012

[22] Eskanlou, A., Khalesi, M.R., Abdollahy, M. and Chegeni, M.H. (2018) Interactional Effects of Bubble Size, Particle Size, and Collector Dosage on Bubble Loading in 
Column Flotation. Journal of Mining \& Environment, 9, 107-116.

[23] Shrimali, K., Atluri, V., Wang, Y., Bacchuwar, S., Wang, X. and Miller, J.D. (2018) The Nature of Hematite Depression with Cornstarch in the Reverse Flotation of Iron Ore. Journal of Colloid and Interface Science, 524, 337-349. https://doi.org/10.1016/j.jcis.2018.04.002

[24] Luo, X., Song, S., Ma, M., Wang, Y., Zhou, Y. and Zhang, Y. (2019) Effect of Particle Size on Flotation Performance of Hematite. Physicochemical Problems of Mineral Processing, 55, 479-493. https://doi.org/10.5277/ppmp18156

[25] Irannajad, M., Nuri, O.S. and Mehdilo, A. (2019) Surface Dissolution-Assisted Mineral Flotation: A Review. Journal of Environmental Chemical Engineering, 7, Article ID: 103050. https://doi.org/10.1016/j.jece.2019.103050

[26] St. Laurent, J.B., de Buzzaccarini, F., De Clerck, K., Demeyere, H., Labeque, R., Lodewick, R. and Langenhove, L. (2007) Laundry Cleaning of Textiles. In: Johansson, I. and Somasundaran, P., Eds., Handbook for Cleaning/ Decontamination of Surfaces, Vol. 1, Elsevier, Amsterdam, 57-102.

https://doi.org/10.1016/B978-044451664-0/50003-6 